\title{
Kaolin Particle Film Applications Can Increase Photosynthesis and Water Use Efficiency of ' Ruby Red' Grapefruit Leaves
}

\author{
John L. Jifon ${ }^{1}$ \\ Texas A\&M University, 2415 East Highway 83, Weslaco TX 78596 \\ James P. Syvertsen \\ Citrus Research and Education Center, University of Florida, IFAS, 700 Experiment Station Road, Lake \\ Alfred, FL 33850
}

\begin{abstract}
AdDitional INDEX WORDS. Surround WP, leaf temperature, vapor pressure deficit, stomatal conductance, chlorophyll fluorescence

Aвstract. Effects of foliar sprays of a kaolin clay particle film (Surround WP) on leaf temperature ( $\left.T_{\text {If }}\right)$, net gas exchange, chlorophyll fluorescence and water relations of sun-exposed leaves on field-grown grapefruit trees (Citrus paradisi L.) were studied during Summer and Fall 2001. Trees were sprayed twice a week for 3 weeks with aqueous suspensions of kaolin (Surround) at $60 \mathrm{~g} \cdot \mathrm{L}^{-1}$. Physiological effects of kaolin application were most prominent around midday on warm sunny days than in mornings, evenings or cloudy days. Kaolin sprays increased leaf whiteness $(62 \%)$, reduced midday leaf temperature $\left(\mathrm{T}_{1 \mathrm{ff}} ; \approx 3{ }^{\circ} \mathrm{C}\right.$ ) and leaf to air vapor pressure differences (VPD; $\approx 20 \%$ ) compared to water-sprayed control leaves. Midday reductions in $\mathrm{T}_{\text {If }}$ and VPD were accompanied by increased stomatal conductance $\left(\mathrm{g}_{\mathrm{s}}\right)$ and net $\mathrm{CO}_{2}$ assimilation rates $\left(\mathbf{A}_{\mathrm{CO} 2}\right)$ of kaolin sprayed leaves, suggesting that $\mathbf{g}_{\mathrm{s}}$ might have limited $\mathbf{A}_{\mathrm{CO} 2}$ in water-sprayed control leaves. Midday photoinhibition of photosynthesis was $30 \%$ lower in kaolin-sprayed leaves than in control leaves. Midday water use efficiency (WUE) of kaolin-sprayed leaves was $25 \%$ higher than that of control leaves. However, leaf transpiration and whole-tree water use were not affected by kaolin film sprays. Increased WUE was therefore, due to higher $\mathrm{A}_{\mathrm{CO} 2}$. Leaf intercellular $\mathrm{CO}_{2}$ partial pressures $\left(\mathrm{C}_{\mathrm{i}}\right)$ were similar in control and kaolin-sprayed leaves indicating that stomatal conductance was not the major cause of reduced $\mathrm{A}_{\mathrm{CO} 2}$. These results demonstrate that kaolin sprays could potentially increase grapefruit leaf carbon uptake efficiency under high radiation and temperature stress.
\end{abstract}

Net $\mathrm{CO}_{2}$ assimilation rates $\left(\mathrm{A}_{\mathrm{CO} 2}\right)$ of most citrus leaves measured in the field are relatively low $\left(4\right.$ to $\left.10 \mu \mathrm{mol} \cdot \mathrm{m}^{-2} \cdot \mathrm{s}^{-1}\right)$ and saturate at relatively low irradiances $\left(\approx 700 \mu \mathrm{mol} \cdot \mathrm{m}^{-2} \cdot \mathrm{s}^{-1}\right) \mathrm{com}-$ pared to deciduous temperate trees (Kriedemann, 1968; Sinclair and Allen, 1982), although higher rates have been measured under greenhouse conditions (Syvertsen and Lloyd, 1994). The low $\mathrm{A}_{\mathrm{CO} 2}$ is believed to be one of the factors limiting citrus productivity (Bustan and Goldschmidt, 1998; Goldschmidt, 1999). Furthermore, $\mathrm{A}_{\mathrm{CO} 2}$ is relatively low when potential evapotranspiration is high, i.e., in high radiation, temperature and vapor pressure deficit environments. Excess radiant energy can lead to large leaf-to-air temperature differences which in turn increase the leaf-to-air vapor pressure difference (VPD) and the potential for transpirational water loss (Jones, 1992). Stomatal conductance $\left(g_{s}\right)$ of citrus leaves is particularly sensitive to changes in VPD (Syvertsen and Salyani, 1991), decreasing with increased VPD at midday. At the same time, however, reduced $g_{s}$ causes transpiration to remain relatively constant (Hall et al., 1975; Kriedemann, 1971; Levy and Syvertsen, 1981; Sinclair and Allen, 1982). Increased VPD and low $\mathrm{g}_{\mathrm{s}}$ at midday can be found even in relatively humid growing conditions in Florida and has been associated with reduced $\mathrm{A}_{\mathrm{CO} 2}$ of citrus leaves (Syvertsen and Lloyd, 1994; Sinclair and Allen, 1982), suggesting that $\mathrm{A}_{\mathrm{CO} 2}$ is limited by $\mathrm{CO}_{2}$ supply. Thus, if $\mathrm{g}_{\mathrm{s}}$ were not sensitive to VDP, leaf carbon uptake potential could increase considerably in a wide

Received for Publication 8 May 2002. Approved for publication 17 Oct. 2002. This research was supported by the Florida Agricultural Experiment Station and a grant from BARD Research Grant No IS2835-97R, a grant from the Florida Citrus Production Research Advisory Council. Approved for publication as Journal Series No. R-08896.

${ }^{1}$ Corresponding author; e-mail jljifon@agprg.tamu.edu. range of citrus growing climates. Since breeding for insensitivity to VPD is probably overly simplistic, alternative methods to reduce the radiation load and VPD could increase carbon uptake capacity and fruit quality (Stanley, 1998; Jifon and Syvertsen, 2001).

Foliar sprays with inert reflective materials such as kaolinite clay have been used in greenhouse and orchard systems to reduce canopy temperatures, water stress, and pest and disease pressures (Baradas et al., 1976; Glenn et al., 1999, 2001; Puterka et al., 2000; Stanhill et al., 1976). Foliar sprays with kaolin reduced canopy temperatures without affecting $\mathrm{A}_{\mathrm{CO} 2}$ or productivity of temperate deciduous fruit trees (Glenn et al., 1999, Tworkoski et al., 2002). Kaolin-sprayed citrus trees also grew larger than nonsprayed control trees (Lapointe, unpublished). A reduction in $\mathrm{T}_{\text {If }}$ would be expected to result in lowered VPD and perhaps increased $\mathrm{g}_{\mathrm{s}}, \mathrm{A}_{\mathrm{CO} 2}$ and water use efficiency (WUE) as has been shown by shading of orange (Citrus sinensis L.) and grapefruit (Citrus paradisi L.) canopies with 50\% shade cloth (Jifon and Syvertsen, 2001). Although the effects of kaolin particle film sprays on pest suppression (Stanley, 1998) and canopy microclimate modification have been described, their effects on leaf physiology are not well understood.

The objective of this study was to evaluate the underlying mechanisms of the effects of kaolin particle film sprays on grapefruit leaf physiology. We hypothesized that foliar sprays with kaolin clay would reduce $\mathrm{T}_{\mathrm{lf}}$ and VPD, bringing about an increase in $\mathrm{g}_{\mathrm{s}}, \mathrm{A}_{\mathrm{CO} 2}$, and WUE in sun exposed leaves. In this study, we compared light reflectance, temperature, water relations, chlorophyll $a$ fluorescence and gas exchange characteristics of kaolin-sprayed and water-sprayed control grapefruit leaves under field conditions during Summer and Fall 2001. 


\section{Materials and Methods}

This study was conducted at the University of Florida's Citrus Research and Education Center, Lake Alfred, Fla. (lat. $28^{\circ} 15^{\prime} \mathrm{N}$, long. $81^{\circ} 62^{\prime} \mathrm{W}$, elevation $51 \mathrm{~m}$ ), using 10 uniform 'Ruby Red' grapefruit (Citrus paradisi L.) trees budded on 'Swingle' citrumelo rootstock. The trees were 5 years old $(1.1 \mathrm{~m}$ tall $)$ and had been grown outdoors since budding in 10-L plastic pots containing a media mix ratio of 1 peat : 1 perlite : 1 pine bark (by volume) (Metro-Mix 500, Scott's Co., Marysville, Ohio). Trees were irrigated daily and fertilized three times per week with a complete water-soluble fertilizer (Peter's Corp, St. Louis, Mo.). All trees were grown in a shade-free location. Kaolin-sprayed and control trees were arranged in a randomized fashion, with 1-m spacing between pots to avoid mutual shading.

Surround WP (Engelhard, Iselin, N.J.), a commercially available kaolin clay material ( $95 \%$ kaolin) with good properties for use as a reflective foliar coating (Glenn et al.,1999), was used for the kaolin spray treatments, following the manufacturer-recommended dosage of $60 \mathrm{~g} \cdot \mathrm{L}^{-1}$ aqueous suspension. Five trees were randomly selected and sprayed on average twice a week with Surround using a hand-held sprayer, while five control trees were sprayed with deionized water only. Each tree was sprayed with $\approx 0.3 \mathrm{~L}$ of Surround suspension to uniformly coat leaves of the entire canopy of each tree with kaolin. In total, 26 kaolin applications were made from 13 Aug. to 9 Nov. 2001 to maintain a uniform coating of kaolin on leaves of treated trees throughout the study period.

Effect of kaolin spray on leaf reflectiveness (whiteness) was measured with a chromameter (CR300; Minolta Corp., Ramsey, N.J.). The whiteness values (L values, range 0 to 100 , where black $=0$ and white $=100$ ) of adaxial leaf surfaces were recorded before and after individual leaves were coated with Surround on 1) both leaf surfaces 2) the adaxial surface only, or 3) the abaxial surface only using a soft paint brush. The effect of coating the adaxial surface only was similar to that of coating both leaf surfaces (Fig. 1) hence trees were sprayed to produce an even film of kaolin clay on the adaxial surfaces.

To determine the effects of kaolin sprays on transmittance of photosynthetically active radiation $(P A R)$, known amounts of Surround suspension were evenly spread on plastic petri plates of known surface area and allowed to dry. Each plate was then placed $50 \mathrm{~cm}$ below a light source (Halogen lamp; Osram Sylvania Inc., Winchester, Ky.) and the photosynthetic photon flux ( $P P F)$ recorded with a quantum sensor (LI-185; LI-COR) placed $10 \mathrm{~cm}$ below the plate. PAR transmittance was estimated as the light level below a coated plate relative to that under a clear, uncoated plate. Light transmittance values were regressed against particle density per unit area $\left(\mathrm{g} \cdot \mathrm{m}^{-2}\right)$. The amount of kaolin $\left(\mathrm{g} \cdot \mathrm{m}^{-2}\right)$ deposited on leaf surfaces was estimated in a separate experiment by evenly spraying Surround on preweighed glass microscope slides of known surface area, drying the slides and reweighing.

$P A R$ and relative humidity were measured at $1.5 \mathrm{~m}$ above the ground and recorded continuously using a dual-sensor weather station (Apogee Instruments, Logan, Utah) located at the experimental site. Leaf temperatures were simultaneously measured with 30-guage copper-constantan (type T) fine-wire thermocouples (Omega Engineering Inc., Stamford, Conn.) connected to dataloggers (CR21X; Campbell Scientific, Logan, Utah). The thermocouple junctions were pressed against the abaxial leaf surfaces and held in place by lightweight clips. Four leaves from each treatment were monitored and data were averaged every 60 min from data collected every $5 \mathrm{~min}$. Air temperatures were measured close to tree canopies using radiation-shielded thermocouples. Leaf to air temperature differences were calculated as the difference between the average leaf ( $n=4$ to 6 ) and air temperatures $(n=2)$. VPD was calculated from $T_{\text {lf }}$ and atmospheric vapor pressure using the equations of Buck (1981).

Leaf $\mathrm{A}_{\mathrm{CO} 2}, \mathrm{~g}_{\mathrm{s}}$, evapotranspiration $(\mathrm{E})$, and WUE $\left(\mathrm{A}_{\mathrm{CO} 2} / \mathrm{E}\right)$ were measured on selected clear sunny days $(1,14$, and 82 after the first spray, DAFS) using at least two mature leaves from exterior canopy positions. Measurements were made in the morning (between 0700 and $1000 \mathrm{HR}$ ), midday (1100 to $1300 \mathrm{HR}$ ), and late afternoon (1500 to $1800 \mathrm{HR}$ ), during each measurement date, using a portable photosynthesis system (LI-6200; LI-COR, Lincoln, Nebr.) equipped with a well-stirred 0.25-L chamber with constant-area inserts $\left(12 \mathrm{~cm}^{2}\right)$. Gas exchange measurements were conducted under natural ambient weather conditions $\left(\mathrm{CO}_{2}\right.$ partial pressure 34 to $38 \mathrm{~Pa}$; saturating $P P F, 1200$ to $\left.1500 \mu \mathrm{mol} \cdot \mathrm{m}^{-2} \cdot \mathrm{s}^{-1}\right) . \mathrm{T}_{\text {If }}$ during measurements ranged from 26 to $39{ }^{\circ} \mathrm{C}$ and air vapor pressure varied from 1.4 to $3.7 \mathrm{kPa}$, depending on time of day. In between measurements, the leaf chamber was placed under shade to minimize deviations in $\mathrm{T}_{\text {lf }}$ and VPD from ambient. Each measurement typically lasted $\approx 50 \mathrm{~s}$ and the order in which trees were measured was completely random.

Chlorophyll $a$ fluorescence was used to diagnose the occurrence and extent of photoinhibition, using a pulse-modulated chlorophyll fluorometer (OS1-FL; Opti-Sciences, Tyngsboro, Mass.). Fluorescence measurements were made following gas exchange measurements and dark-adaptation for 30 min using leaf clips (FL-DC; Opti-Science). The maximum efficiency of photosystem II (PSII) photochemistry $\left(\mathrm{F}_{\mathrm{v}} / \mathrm{F}_{\mathrm{m}}\right)$ was determined following the procedures described by Maxwell and Johnson (2000), where $F_{v}$ is variable fluorescence $=F_{m}-F_{o} ; F_{o}$ is the minimal (ground) fluorescence intensity, and $F_{m}$ is maximal fluorescence intensity following a 1-s saturating flash $(P P F>5$ $\mathrm{mmol} \cdot \mathrm{m}^{-2} \cdot \mathrm{s}^{-1}$ ) of light. Percent photoinhibition was calculated by dividing the $\mathrm{F}_{\mathrm{v}} / \mathrm{F}_{\mathrm{m}}$ value at any given time during the day by the predawn value. Following gas exchange and chlorophyll fluorescence measurements, two leaf discs $\left(1 \mathrm{~cm}^{2}\right.$ each) were collected from the measurement leaf and used for chlorophyll determination. Chlorophyll was eluted with dimethylformamide and quantified using the equations of Wellburn (1994), after recording optical densities at 647 and $664 \mathrm{~nm}$ with a spectrophotometer (UV2401PC; Shimadzu, Columbia, Md.).

Leaf water potentials $\left(\Psi_{1}\right)$ were measured during the course of two selected clear days (82 and 83 DAFS) using a Scholandertype pressure chamber (PMS Instruments, Corvalis, Ore.). $\Psi_{1}$ was measured at dawn (before $0600 \mathrm{HR}$ ) and around midday (1200 to $1300 \mathrm{HR}$ ) using at least three leaves of similar age, collected from the same shoots as leaves used in gas exchange measurements. Whole-tree water use was also measured over the same 2-d period by weighing the pots at the beginning and end of the photoperiod. Each pot was covered with a white plastic bag to minimize water evaporation from the soil.

Statistical analysis. Single leaf gas exchange and chlorophyll fluorescence measurements were made three times $(1,14$, and 82 DAFS) using five replicate trees per treatment and at least two mature leaf samples per tree. Measurements were also made at various times of the day to study the diurnal response to kaolin spray.

Data were analyzed as a completely randomized split-plot design with repeated measures (Littell, 1989; Moser et al., 1990), according to the general linear model procedure of the Statistical 
Analysis System (SAS Institute Inc., Cary, N.C.). Significance of kaolin sprays (main plot) was tested with the main plot experimental error (error a), whereas the effect of measurement date and time of day (subplots) was tested with the subplot experimental error (error b) (Steel and Torrie, 1980). Where appropriate, regression models were fitted to the response variables. Even though measurements were made on clear days, physiological variables differed according to measurement date because of differences in the absolute air vapor pressure and the physiological status of the trees between these dates. However, the diurnal response patterns to kaolin spray were similar across all measurement dates. For brevity, only representative data from dates with the most sampling points are presented.

\section{Results}

LIGHT REFLECTANCE AND TRANSMITTANCE. Light reflected from kaolin-sprayed leaves was $62 \%$ whiter than that reflected from control water-sprayed leaves (Fig. 1). The reflectance of leaves coated on the adaxial surface alone was similar to that of leaves coated on both surfaces whereas the reflectance of leaves coated on the abaxial surface only was not different from that of control leaves. Light transmittance declined exponentially with increasing area particle density of kaolin (Fig. 2). Uniform foliar sprays with a $60 \mathrm{~g} \cdot \mathrm{L}^{-1}$ Surround aqueous suspension deposited on average, $5.51 \pm 0.48 \mathrm{~g}$ kaolin particles per square meter of surface area and reduced $P A R$ transmittance by $\approx 28 \%$ (Fig. 2).

ENVIRONMENTAL AND CANOPY MICROCLIMATE CONDITIONS. On cloudless days, the average hourly PAR peaked slightly above $1900 \mu \mathrm{mol} \cdot \mathrm{m}^{-2} \cdot \mathrm{s}^{-1}$ around midday (Fig. 3a). Air temperatures followed a similar pattern as $P A R$ but had a broader peak from $\approx 1200$ to $1800 \mathrm{HR}$, occasionally exceeding $35^{\circ} \mathrm{C}$ around $1300 \mathrm{HR}$. The largest reductions in leaf to air temperature differences (Fig. 3b) and VPD (Fig. 3c) by kaolin sprays were observed around

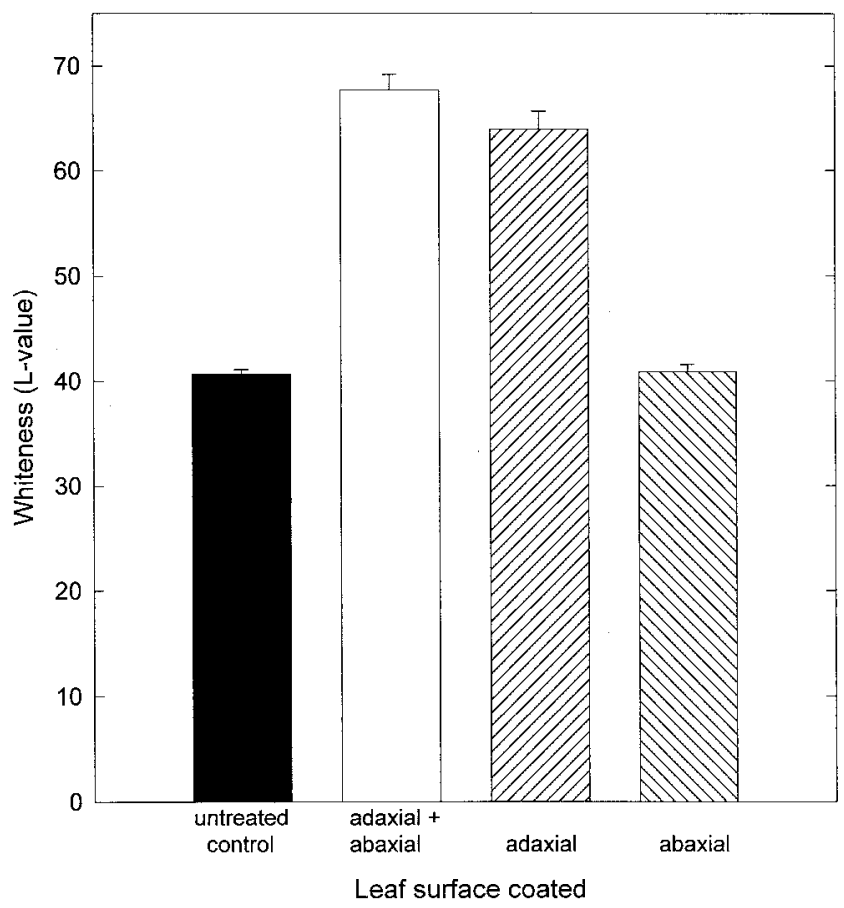

Fig. 1. Effect of kaolin clay coating on 1) both leaf surfaces, 2) the adaxial leaf surfaces only, or 3) the abaxial surfaces on the whiteness of citrus leaves. Leaf whiteness was measured as tristimulus L values (range 0 to 100) where black = 0 and white $=100$. Each bar is a mean \pm standard error, $n=10$. midday (1100 to $1400 \mathrm{HR}$ ) when PAR was highest. Around midday, sunlit kaolin-coated leaves were on average $3{ }^{\circ} \mathrm{C}$ cooler than sunlit control leaves and only $\approx 1.5^{\circ} \mathrm{C}$ warmer than air temperature. Control leaves were 2 to $5{ }^{\circ} \mathrm{C}$ warmer than air temperatures during most cloudless days (Fig. 3b). The maximum air vapor pressure (VP) during measurement dates varied from $\approx 3.0 \mathrm{kPa}$ (1 DAFS, in August) to $1.9 \mathrm{kPa}$ (82 DAFS, in November; data not shown), even though these were cloudless days. The VPDs of sunlit kaolin-sprayed leaves were on average $20 \%$ lower, and less variable, than those of sunlit control leaves (Fig. 3c).

GaS EXChANGE AND CHLOROPHYLL FLuORESCENCE. Physiological responses to kaolin sprays followed similar diurnal patterns but differed according to measurement date $(P<0.047$; data not shown) due to differences in air VP. Representative data from 14 DAFS are shown in Fig. 4. In the mornings, leaf gas exchange parameters were similar among kaolin-sprayed and control leaves, but around midday and afternoons, $\mathrm{g}_{\mathrm{s}}$ and $\mathrm{A}_{\mathrm{CO} 2}$ were significantly higher in kaolin-sprayed than in control leaves $(P<0.02$ for time of day by kaolin interaction). Leaf $\mathrm{g}_{\mathrm{s}}$ and $\mathrm{A}_{\mathrm{CO} 2}$ reached maximum values between 0800 and $1000 \mathrm{HR}$ (Fig. 4a and b), with no significant differences between kaolin-coated and control leaves. Midday depression of $\mathrm{g}_{\mathrm{s}}$ and $\mathrm{A}_{\mathrm{CO} 2}$ corresponded with periods of high $P A R$, temperatures and VPD. The intercellular $\mathrm{CO}_{2}$ partial pressure $\left(\mathrm{C}_{\mathrm{i}}\right)$ declined along with $\mathrm{g}_{\mathrm{s}}$ and $\mathrm{A}_{\mathrm{CO} 2}$ during the course of the day, but there were no significant differences in $\mathrm{C}_{\mathrm{i}}(P>0.8)$ between kaolin-sprayed and control leaves (Fig. 4c). E increased to maximal values of $\approx 4 \mathrm{mmol} \cdot \mathrm{m}^{-2} \cdot \mathrm{s}^{-1}$ for most of the photoperiod, but did not differ between kaolin-sprayed and control leaves $(P=0.3$; data not shown). Leaf WUE was highest during morning hours but declined rapidly to stable values by $1000 \mathrm{HR}$. Early in the morning, kaolin sprays had no effect on WUE, but between 1000 and $1300 \mathrm{HR}$, the WUE of kaolin-sprayed leaves was 25\% higher than that of control leaves (Fig. 4d).

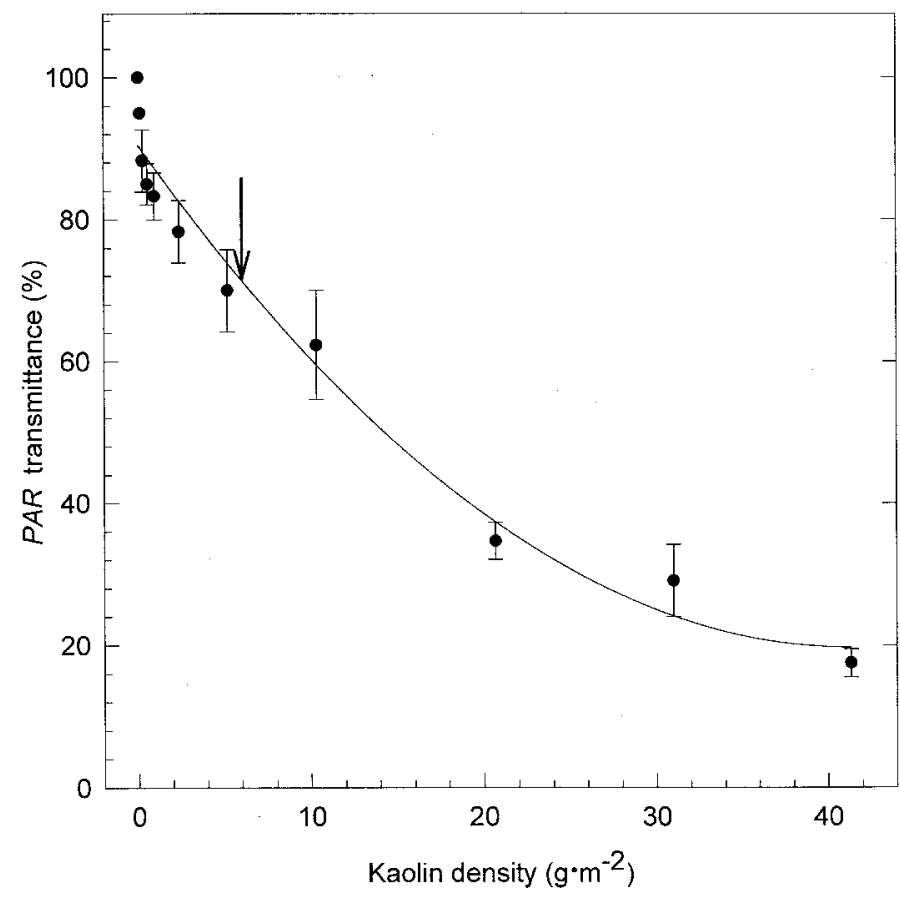

Fig. 2. Transmittance of photosynthetically active radiation $(P A R)$ through thin clear plastic surfaces coated with varying amounts of kaolin clay. Arrow indicates the estimated concentration of kaolin particles deposited per unit leaf area (5.5 $\mathrm{g} \cdot \mathrm{m}^{-2}$; Transmittance $=72 \%$ ) after spraying with a $60-\mathrm{g} \cdot \mathrm{L}^{-1} \mathrm{kaolin}$ suspension. Eq.: Transmittance $=89.77 \mathrm{e}^{-0.0394 \mathrm{x}} ; \mathrm{x}=$ density of kaolin, $\mathrm{g} \cdot \mathrm{m}^{-2} ; R^{2}=0.98$. 
Although chlorophyll $a$ fluorescence differed between measurement dates $(P<0.03)$, the diurnal patterns in all fluorescence parameters were similar across dates. Representative data from 14 DAFS are shown in Fig. 5. At dawn, $F_{v} / F_{m}$ values were high and similar among kaolin-sprayed and control leaves (mean $0.810 \pm$ 0.006; Fig. 5a). However, as $P P F$ exceeded $1200 \mu \mathrm{mol} \cdot \mathrm{m}^{-2} \cdot \mathrm{s}^{-1}, \mathrm{~F}_{\mathrm{v}} l$ $\mathrm{F}_{\mathrm{m}}$ of all leaves declined indicating an increase in photoinhibition of photosynthesis (Fig. 5a). Between 1000 and $1600 \mathrm{HR}, \mathrm{F}_{\mathrm{v}} / \mathrm{F}_{\mathrm{m}}$ values were $3 \%$ to $6 \%$ higher in kaolin-sprayed leaves compared to control leaves. Photoinhibition of photosynthesis in kaolinsprayed leaves was $\approx 30 \%$ lower than that in control leaves. All leaves showed some degree of late-afternoon recovery from photoinhibition such that by the following morning, $\mathrm{F}_{\mathrm{v}} / \mathrm{F}_{\mathrm{m}}$ values were again as high as in the previous morning (data not shown). On hot cloudless days, there was usually a sharp increase in the ground fluorescence $\left(\mathrm{F}_{\mathrm{o}}\right)$ of control leaves around midday when $P A R$ levels were highest (Fig. 5c). Kaolin sprays did not affect total chlorophyll content per unit leaf area $(P=0.22$; average 0.57 $\left.\pm 0.02 \mathrm{~g} \cdot \mathrm{m}^{-2}\right)$.

LEAF WATER POTENTIAL AND TREE WATER USE. Leaf water potential declined during the course of the day, with minimum values occurring around $1300 \mathrm{HR}$ (average $-1.77 \pm 0.08$ and -1.76 $\pm 0.05 \mathrm{MPa}$ for kaolin-sprayed and control leaves, respectively; $P=0.92$ ). Average whole-tree daily water use was not affected by

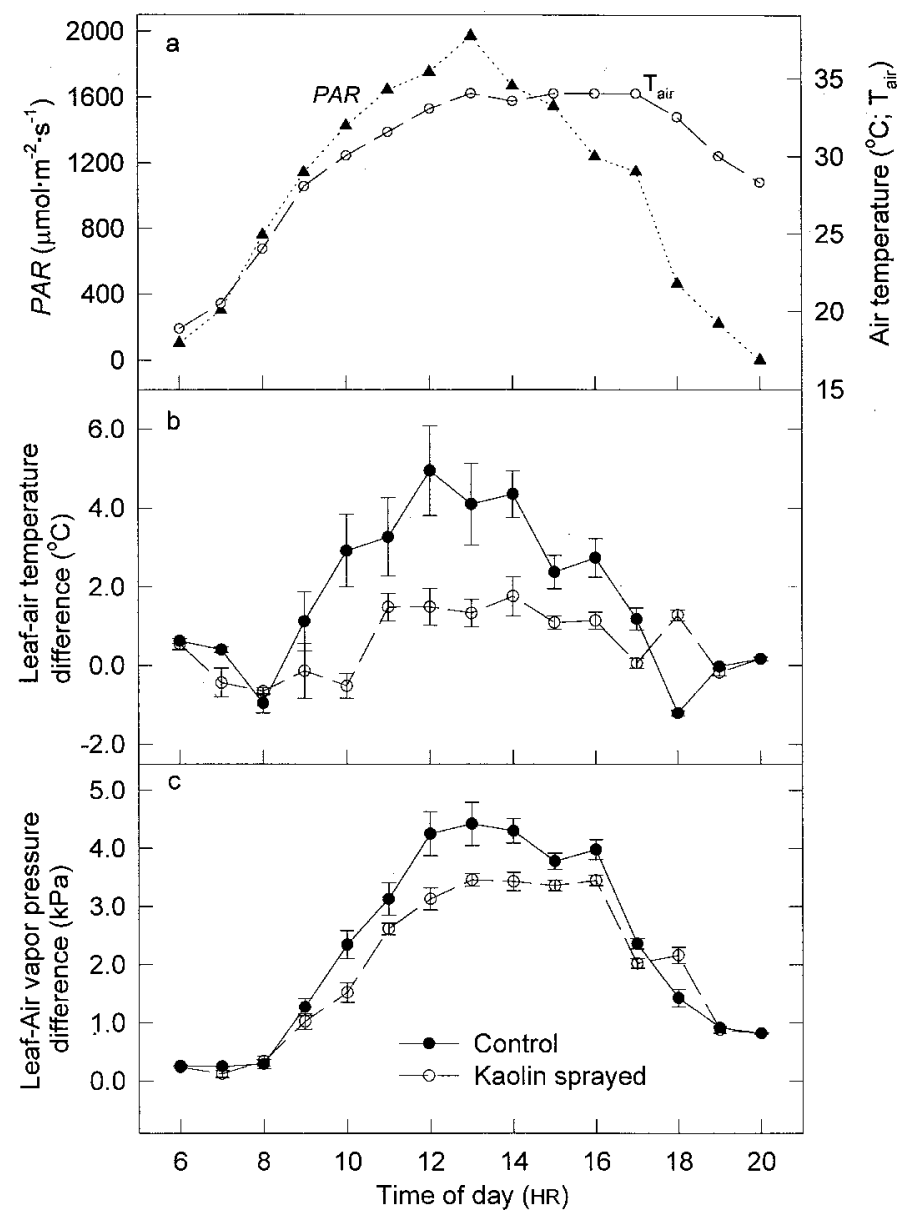

Fig. 3. Incident photosynthetically active radiation $(P A R)$ and air temperature (a), leaf-to-air temperature differences $(\mathbf{b})$, and leaf-to-air vapor pressure differences (c) of kaolin sprayed and control grapefruit leaves grown in full sunlight. Data collected at $14 \mathrm{~d}$ after the first spray (27 Aug. 2001). Error bars indicate SE $(\mathrm{n}=$ 4 to 6$)$. kaolin sprays $(P=0.53$; data not shown), however, kaolinsprayed trees used slightly more water $(12 \%)$ than control trees.

\section{Discussion}

Increased leaf whiteness as a result of kaolin sprays was accompanied by significant reductions in $\mathrm{T}_{\text {If }}$ and VPD on clear days when incident $P A R$ exceeded $1500 \mu \mathrm{mol} \cdot \mathrm{m}^{-2} \cdot \mathrm{s}^{-1}$ and air temperatures were $>30^{\circ} \mathrm{C}$. Increased reflection of incident shortand long-wave radiation from the white colored kaolin-sprayed leaves was probably responsible for the temperature reduction. Glenn et al. (1999) found a 3- to 4-fold increase in the spectral radiance in the visible spectrum reflected from tree canopies sprayed with kaolin at $30 \mathrm{~g} \cdot \mathrm{m}^{-2}$ leaf surface, and a $3{ }^{\circ} \mathrm{C}$ reduction in $\mathrm{T}_{\mathrm{ff}}$. In the present study, kaolin sprays also reduced grapefruit $\mathrm{T}_{\text {lf }}$ at midday by $\approx 3^{\circ} \mathrm{C}$. At night, kaolin-sprayed and control leaves had similar temperatures implying that long-wave emittance was unaffected by kaolin sprays. The variability in light transmittance (Fig. 2, error bars) probably approximates nonuniform particle deposition on leaves as might occur in the field. The higher variability in leaf to air temperature difference and VPD of control leaves compared to kaolin sprayed leaves (Fig. 3 b and c) suggests that the kaolin coating may have insulated leaves from changes in air temperature.

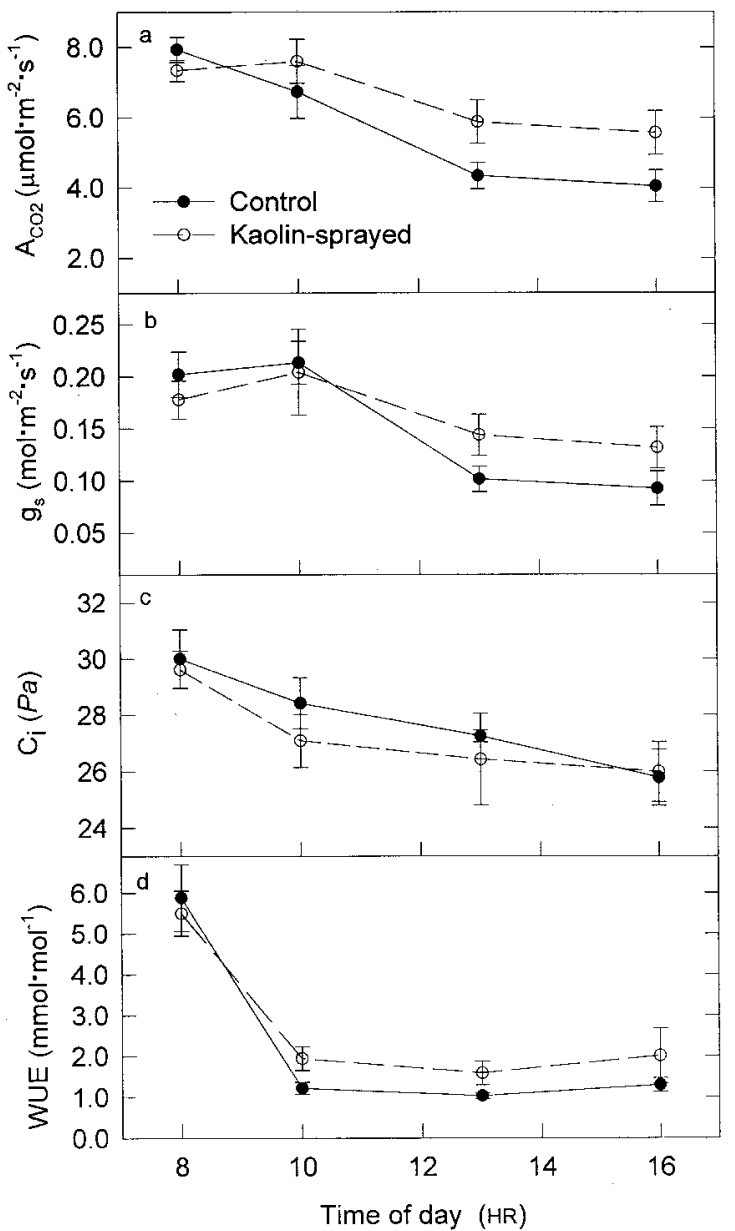

Fig. 4. Effects of kaolin sprays on net $\mathrm{CO}_{2}$ assimilation rates $\left(\mathrm{A}_{\mathrm{CO} 2}\right)(\mathbf{a})$, stomatal conductance $\left(\mathrm{g}_{\mathrm{s}}\right)(\mathbf{b})$, internal $\mathrm{CO}_{2}$ partial pressure $\left(\mathrm{C}_{\mathrm{i}}\right)(\mathbf{c})$, and water use efficiency (WUE) (d) of kaolin-sprayed and water-sprayed grapefruit leaves grown and measured in full sunlight. Data collected at $14 \mathrm{~d}$ after the first spray (27 Aug. 2001). 
Reduced $\mathrm{T}_{\mathrm{ff}}$ and VPD were accompanied by increased $\mathrm{g}_{\mathrm{s}}, \mathrm{A}_{\mathrm{CO} 2}$, and WUE of sprayed, compared to control leaves. The higher midday $\mathrm{A}_{\mathrm{CO} 2}$ of kaolin-sprayed leaves relative to controls could be due to increased $g_{s}$ in response to reduced $T_{\text {lf }}$ and VPD. The relatively high sensitivity of citrus $g_{s}$ to VPD often results in reduced E (Hall et al., 1975; Kriedemann, 1971; Syvertsen and Salyani, 1991; Levy and Syvertsen, 1981), and has been associated with reduced $\mathrm{A}_{\mathrm{CO} 2}$ (Sinclair and Allen, 1982; Khairi and Hall, 1976). The close association between $g_{s}$ and $A_{\mathrm{CO} 2}$ (Fig. 4a and b) suggests a causal relationship between these variables. Where $\mathrm{CO}_{2}$ diffusion limits $\mathrm{A}_{\mathrm{CO} 2}$, a decrease in $\mathrm{C}_{\mathrm{i}}$ would occur at the same time (Farquhar and Sharkey 1982). $C_{i}$ generally decreased during the course of the day (Fig. 4c) but did not differ between kaolinsprayed and control leaves. The physical presence of the clay particles apparently did not inhibit leaf gas exchange, perhaps due to the porous nature of kaolin clay (Glenn et al., 1999) or nonuniform particle adhesion to the rather smooth citrus leaves. The similarity in $\mathrm{C}_{\mathrm{i}}$ between sprayed and control leaves, suggests that $\mathrm{CO}_{2}$ supply via stomata (i.e., $\mathrm{g}_{\mathrm{s}}$ ) was not the major factor limiting $\mathrm{A}_{\mathrm{CO} 2}$.

Several factors, including direct and indirect effects of supraoptimal $\mathrm{T}_{\text {lf }}$ and photoinhibition around midday, probably contributed to nonstomatal limitation of $\mathrm{A}_{\mathrm{CO} 2}$ (Jifon and Syvertsen,

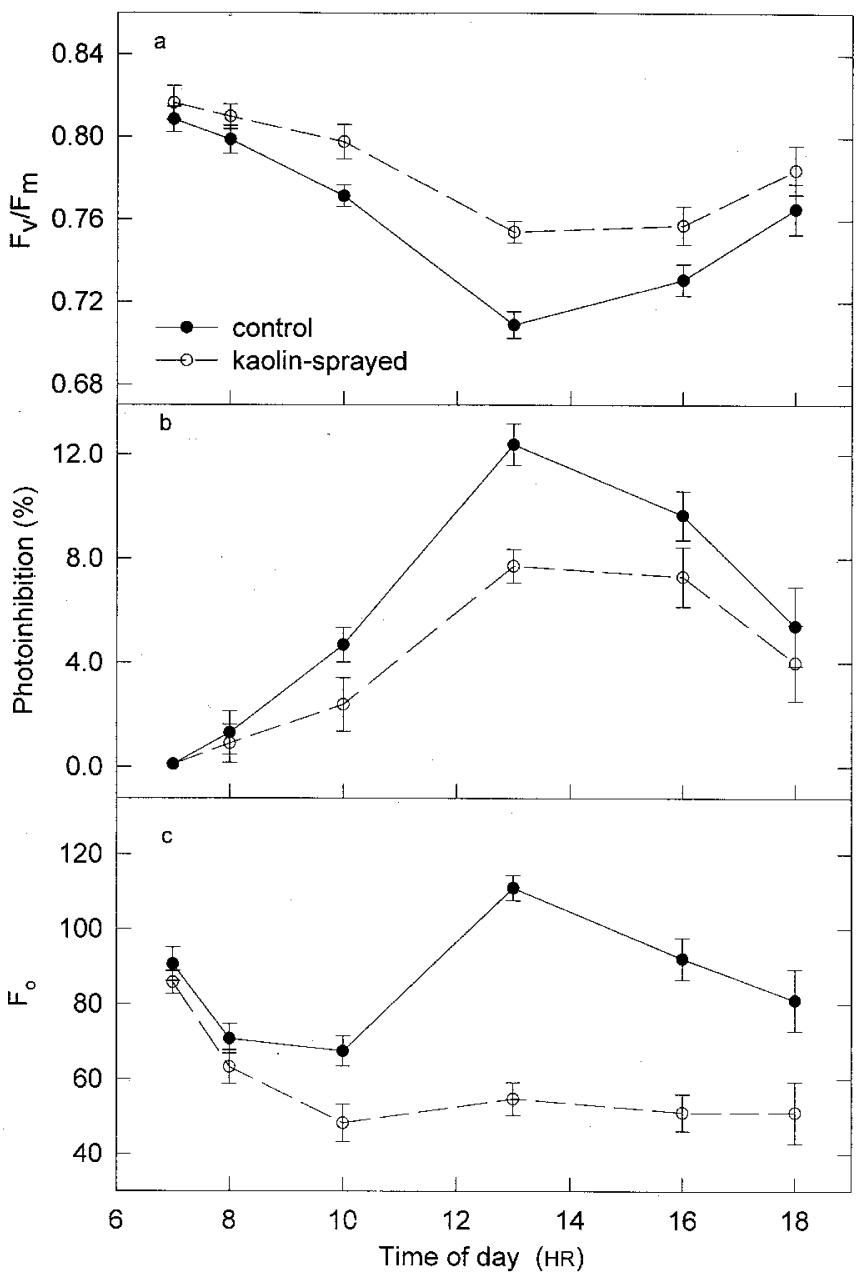

Fig. 5. Diurnal time course of chlorophyll a fluorescence: (a) maximum efficiency of photosystem II photochemistry, $\mathrm{F}_{\mathrm{v}} / \mathrm{F}_{\mathrm{m}}$, (b) percent photoinhibition, and (c) ground fluorescence, $F_{o}$ of kaolin-sprayed and water-sprayed grapefruit leaves grown and measured in full sunlight. Photoinhibition was calculated as the $F_{v} /$ $\mathrm{F}_{\mathrm{m}}$ during the day divided by the predawn value. Error bars indicate $\mathrm{SE}(\mathrm{n}=5$ to 10). Data collected at $14 \mathrm{~d}$ after the first spray (27 Aug. 2001).
2002). $A_{\mathrm{CO} 2}$ of all treatments generally decreased with increasing temperature during the day, but that of nontreated control leaves had a greater proportional decrease than that of kaolin-sprayed leaves. The optimum temperature for citrus $\mathrm{A}_{\mathrm{CO} 2}$ varies from 15 to $30^{\circ} \mathrm{C}$ depending on humidity (Kriedemann, 1968, Khairi and Hall, 1976). During our study, air temperatures and VPD on cloudless days during our study typically exceeded $30^{\circ} \mathrm{C}$ and 2 $\mathrm{kPa}$, respectively, and $\mathrm{T}_{\mathrm{lf}}$ of control plants occasionally exceeded $35^{\circ} \mathrm{C}$. On such days, the ensuing heat stress could have limited $\mathrm{A}_{\mathrm{CO} 2}$ by damaging photosynthetic membranes, deactivating Calvin cycle enzymes (Law and Crafts-Brandner, 1999), and/or inhibiting photoassimilate metabolism (reducing sink strength). Heatstress-induced limitation on photoassimilate use can inhibit $\mathrm{A}_{\mathrm{CO} 2}$ indirectly by reducing the rate at which inorganic phosphate is recycled from the cytosol to support electron transport and carbon fixation in the chloroplast (Sharkey, 1994). Reduced sink strength can also lead to carbohydrate accumulation in leaves and lower $\mathrm{A}_{\mathrm{CO} 2}$ by damaging photosynthetic membranes (Azcón-Bieto, 1983; Nafziger and Koller, 1976).

The degree of photoinhibition $\left(\mathrm{F}_{\mathrm{v}} / \mathrm{F}_{\mathrm{m}}\right.$ relative to the dawn value) increased with increasing $P A R$ and $\mathrm{T}_{\text {lf }}$ with maximum values occurring in control leaves and around midday (Fig. 5b). Photoinhibition of photosynthesis arises from overexcitation of photochemical systems and is believed to have a regulatory as well as a protective function (Demmig-Adams et al., 1997). Regulatory mechanisms involving xanthophyll pigments can dissipate excess energy as heat, thereby, protecting the photosynthetic apparatus from photodamage (Gilmore and Ball, 2000). The sharp increase in $\mathrm{F}_{\mathrm{o}}$ (Fig. 5c) indicated that perturbations in chloroplast membrane structure might have contributed to increased photoinhibition (Yamane et al., 1997). Reversible reduction in $\mathrm{A}_{\mathrm{CO} 2}$ at midday could therefore be due, at least in part, to reduced photochemical efficiency as well as other nonstomatal factors such as increased photorespiration and dark respiration due to high $\mathrm{T}_{\mathrm{lf}}$ (Long, 1991; Jordan and Ogren, 1984).

Kaolin spray-induced reductions in $\mathrm{T}_{\mathrm{lf}}$ and VPD and the resultant increase in $g_{s}$ could potentially increase transpiration and tree water use as has been reported for apple grown in a temperate climate (Glenn et al., 2001). Although stomata were more open in sprayed than control leaves, the VPD (driving force for transpiration) of kaolin-sprayed leaves was lower than that of control leaves, hence, leaf transpiration and whole-tree water use were not affected by kaolin sprays. Reductions in water use as a result of kaolin spray have been reported in sorghum (Stanhill et al., 1976), cotton (Moreshet et al., 1979), and soybean (Baradas et al., 1976). The differences between our data and previous results could be due to species differences in sensitivity of $g_{s}$ to VPD, growth environment, or perhaps differences in the kaolin formulations used (Puterka et al., 2000). High sensitivity of $g_{s}$ to VPD is well documented in citrus (Hall et al., 1975; Syvertsen and Salyani, 1991), and contributes to the relatively low evapotranspiration rates of citrus compared to other crops under similar climatic conditions (Levy and Syvertsen, 1981; Sinclair and Allen, 1982). Reduction of $g_{s}$ during periods of high VPD limits water loss and is believed to a physiological mechanism that allows citrus to survive in semiarid environments with high evaporative demands (Syvertsen and Lloyd, 1994).

In studies with temperate deciduous trees, Glenn et al. (1999) reported that kaolin sprays at $30 \mathrm{~g} \cdot \mathrm{m}^{-2}$ reduced canopy temperatures by $\approx 3^{\circ} \mathrm{C}$; however, photosynthetic activity measured under near optimal physiological conditions $\left(20^{\circ} \mathrm{C}, 70 \% \mathrm{RH}\right)$, was not affected. Their results were similar to the morning (0800 to 1000 
HR) results reported here but around midday when temperatures and VPD were high, there was a clear enhancement of citrus leaf $\mathrm{g}_{\mathrm{s}}, \mathrm{A}_{\mathrm{CO} 2}$, and PSII photochemistry by kaolin spray. Thus, during the cool morning hours, it is not surprising that kaolin spray had little effect on leaf physiology.

In summary, foliar sprays of kaolin reduced $\mathrm{T}_{\mathrm{lf}}$ and VPD and increased leaf $\mathrm{g}_{\mathrm{s}}, \mathrm{A}_{\mathrm{CO} 2}$ and WUE of mature sun-acclimated grapefruit leaves during hot days. The mechanisms for improved gas exchange characteristics involved both increased $\mathrm{g}_{\mathrm{s}}$ and nonstomatal factors. With little or no pest pressure, improved WUE was due to increased $\mathrm{A}_{\mathrm{CO} 2}$ as leaf $\mathrm{E}$ and tree water use were not affected by kaolin sprays. Kaolin spray was most beneficial under midday conditions when high incident light elevated $\mathrm{T}_{\mathrm{lf}}$ and VPD. From these data, it can be speculated that in warm citrus producing regions, where high radiation and VPD can limit photosynthetic capacity, kaolin sprays could improve leaf carbon uptake potential especially in young trees or trees with small canopies where most of the leaves are exposed to direct sunlight. This remains to be tested for whole trees and related to any growth or production response.

\section{Literature Cited}

Azcón-Bieto, J. 1983. Inhibition of photosynthesis by carbohydrates in wheat leaves. Plant Physiol. 73:681-686.

Baradas, M.W., B.L. Blad, and N.J. Rosenberg. 1976. Reflectant induced modification of soybean canopy radiation balance IV. Leaf and canopy temperature. Agron. J. 68:843-848.

Buck, A.L. 1981. New equations for computing vapor pressure. J. Appl. Meteorol. 20:1527-1532.

Bustan, A. and E.E. Goldschmidt. 1998. Estimating the cost of flowering in a grapefruit tree. Plant Cell Environ. 21:217-224.

Demmig-Adams, B., W.W. Adams, III, and S.C. Grace. 1997. Physiology of light tolerance in plants. Hort. Rev. 18:215-246.

Farquhar, G.D. and T.D. Sharkey. 1982. Stomatal conductance and photosynthesis. Annu. Rev. Plant Physiol. Plant Mol. Biol. 33:317345.

Gilmore, A.M. and M.C. Ball. 2000. Protection and storage of chlorophyll in overwintering evergreens. PNAS 97:11098-11101.

Glenn, D.M., G.J. Puterka, S.R. Drake, T.R. Unruh, A.L. Knight, P. Baherle, E. Prado, and T.A. Baugher. 2001. Particle film application influences apple leaf physiology, fruit yield, and fruit quality. J. Amer. Soc. Hort. Sci. 126:175-181.

Glenn, D.M., G.J. Puterka, T. Vanderzwet, R.E. Byers, and C. Feldhake. 1999. Hydrophobic particle films: A new paradigm for suppression of arthropod pests and plant diseases. J. Econ. Entomol. 92:759-771.

Goldschmidt, E.E. 1999. Carbohydrate supply as a critical factor for citrus fruit development and productivity. HortScience 34:1020-1024.

Hall A.E., S.E. Camacho-B, and M.R. Kaufmann. 1975. Regulation of water loss by citrus leaves. Physiol. Plant. 33:62-65.

Jifon, J.L. and J.P. Syvertsen. 2001. Effects of moderate shade on Citrus leaf gas exchange, fruit yield and quality. Proc. Fla. State Hort. Soc. 114:177-181.

Jifon, J.L. and J.P. Syvertsen. 2002. Moderate shade can increase net gas exchange and reduce photoinhibition in citrus leaves. Tree Physiol. 23: in press.

Jones, G.H. 1992. Plants and microclimate: A quantitative approach to environmental plant physiology. $2^{\text {nd }}$ ed., Cambridge Univ. Press, Cambridge, U.K.

Jordan, D.B. and W.L. Ogren. 1984. The $\mathrm{CO}_{2} / \mathrm{O}_{2}$ specificity of ribulose1,5-bisphosphate carboxylase/oxygenase. Dependence on ribulose1,5-bisphosphate concentration, $\mathrm{pH}$, and temperature. Planta 161:308313.
Khairi, M.M.A. and A.E. Hall. 1976. Temperature and humidity effects on net photosynthesis and transpiration of citrus. Physiol. Plant. 36:2934.

Kriedemann, P.E. 1968. Some photosynthetic characteristics of citrus leaves. Austral. J. Biol. Sci. 21:895-905.

Kriedemann, P.E. 1971. Photosynthesis and transpiration as a function of gaseous diffusive resistances in orange leaves. Physiol. Plant. 24:218-225.

Law, R.D. and S.J. Crafts-Brandner. 1999. Inhibition and acclimation of photosynthesis to heat stress is closely correlated with activation of ribulose-1,5-bisphosphate carboxylase/oxygenase. Plant Physiol. 120:173-181.

Levy, Y. and J.P. Syvertsen. 1981. Water relations of citrus in climates with different evaporative demands. Proc. Intl. Soc. Citricult. 2:501503.

Littell, R.C. 1989. Statistical analysis of experiments with repeated measures. HortScience 24:37-40.

Long, S.P. 1991. Modification of the response of photosynthetic productivity to rising temperature by atmospheric $\mathrm{CO}_{2}$ concentrations: Has its importance been underestimated? Plant Cell Environ. 14:729-739.

Maxwell, K. and G.N. Johnson. 2000. Chlorophyll fluorescence-A practical guide. J. Expt. Bot. 51:659-668.

Moser, E.B., A.M. Saxton, and S.R. Pezeshki. 1990. Repeated measures analysis of variance: Application to tree research. Can. J. For. Res. 20:524-535.

Moreshet, S., Y. Cohen, and M. Fuchs. 1979. Effect of increasing foliage reflectance on yield, growth, and physiological behavior of a dry land cotton crop. Crop Sci. 19:863-868.

Nafziger, E.D. and H.R. Koller. 1976. Influence of leaf starch concentration on $\mathrm{CO}_{2}$ assimilation in soybean. Plant Physiol. 57:560-563.

Puterka, G.J., D.M. Glenn, D.G. Sekutowski, T.R. Unruh, and S.K. Jones. 2000. Progress toward liquid formulations of particle films for insect and disease control in pear. Environ. Entomol. 29:329-339.

Sharkey, T.D. 1994. Feedback effects on photosynthesis induced by assay and growth at high carbon dioxide, p. 461-466. In: K.J. Boote, J.M. Bennet, T.R. Sinclair and G.M. Paulsen (eds.). Physiology and determination of yield. Amer. Soc. Agron., Inc., Madison, Wis.

Sinclair, T.R. and L.H. Allen, Jr. 1982. Carbon dioxide and water vapor exchange of leaves on field-grown citrus trees. J. Expt. Bot. 33:11661175.

Stanhill, G., S. Moreshet, and M. Fuchs. 1976. Effect of increasing foliage and soil reflectivity on the yield and water use efficiency of grain sorghum. Agron. J. 68:329-332.

Stanley D. 1998. Particle Films: A new kind of crop protectant. Agr. Res. (Nov.):16-19.

Steel, R.G.D. and J.H. Torrie. 1980. Principles and Procedures of Statistics: A Biometrical Approach. 2ed. McGraw-Hill, New York.

Syvertsen, J.P. and J. Lloyd. 1994. Citrus, p. 65-99. In: B. Schaffer and P.C. Andersen (eds.). Handbook of environmental physiology of fruit crops. vol. 2. Sub-tropical and tropical crops. CRC Press, Boca Raton, Fla.

Syvertsen, J.P. and M. Salyani. 1991. Petroleum spray oil effects on net gas exchange of grapefruit leaves at various vapor pressures. HortScience 26:168-170.

Tworkoski, T.J., D.M. Glenn, and G.J. Puterka. 2002. Response of beans to applications of hydrophobic mineral particles. Can. J. Plant Sci. 82:217-219.

Wellburn, A.R. 1994. The spectral determination of chlorophylls $a$ and $b$, as well as carotenoids, using various solvents with spectrophotometers of different resolution. J. Plant Physiol. 144:307-313.

Yamane, Y., Y. Kasino, H. Koike, and K. Satoh. 1997. Increases in the fluorescence $\mathrm{F}_{\mathrm{o}}$ level and reversible inhibition of Photosystem II reaction center by high-temperature treatments in higher plants. Photosyn. Res. 52:57-64. 